\title{
Halal Tourism in Indonesia: a Study on Lake Toba
}

\author{
Aprinawati $^{1}$, Rangga Restu Prayogo ${ }^{2}$, Gaffar Hafidz Sagala ${ }^{3}$, Dedi Yusrizal ${ }^{4}$ \\ \{ aprinawati@unimed.ac.id ${ }^{1}$, ranggarestuprayogo@ unimed.ac.id ${ }^{2}$, hafizsagala@unimed.ac.id ${ }^{3}$, \\ dediyusrizal@unimed.ac.id\} \\ Department of Management, Faculty of Economics, UNIMED ${ }^{1}$ \\ Department of Entrepreneurship, Faculty of Economics, UNIMED ${ }^{2}$ \\ Department of Digital Business, Faculty of Economics, UNIMED ${ }^{3}$ \\ Department of Digital Business, Faculty of Economics, UNIMED ${ }^{4}$
}

\begin{abstract}
Halal tourism is a new style in the tourism sectors. Muslims form one of the world's largest markets, knowledge related to different Islamic perspectives and contradicting the concept of tourism in general. The halal lifestyle provides opportunities for Muslim tourists to enjoy traveling, including Lake Toba Indonesia's tourist attraction. This study aims to determine the relationship travel attitude and travel lifestyle on halal in Lake Toba Indonesia. This research is a quantitative explanative with a sample of 200 tourists visiting the tourist area of Lake Toba with a purposive technique and using Structural Equational Modeling (SEM). The results showed that travel attitude affects travel lifestyle, travel attitude affects halal tourism, travel attitude affects halal tourism.
\end{abstract}

Keywords: Travel attitude, Travel Lifestyle, Halal Industry, Lake Toba

\section{Introduction}

The result of the studies [1] Explaining the relationship between religion and tourism separately on religion or tourism and paying less attention to the actual interaction or relationship, then a good understanding cannot be built and developed without a deep understanding of the topic of tourism. about religion, its practices, and opinions on tourism and tourism activities. Therefore, there is a great demand for research that can define and interact with various tourism and various aspects of religion. One of the tourism concepts being developed is Islamic tourism (Islamic tourism). The concept of tourism still forms the stigma that all tourism activities must use Islamic values as an appropriate reference. Although Muslims are one of the world's largest markets for tourism enthusiasts, knowledge is linked to an Islamic perspective that has a distinct contrast to the perception of tourism in general. Several experts have defined Islamic tourism. According to [2], tourism is all tourism activities carried out by Muslims that originate from Islamic motivation and are realized in accordance with the principles of sharia. The statement also stated by [3], which stated that Islamic tourism is a product development and marketing effort to be developed and directed at Muslims. Some of the definitions above, Islamic tourism focuses on many differences that are oriented towards activities based on Islamic rules [4]. There are differences regarding the definition of halal tourism and the teachings of halal and haram, which are used differently, but the two definitions conclude that tourism is a journey undertaken by Muslims who seek to adhere to religious principles when tourists travel. The results of the study, identified in terms of terminology and clarified the concept, the most commonly used terms were "halal tourism" and "Islamic tourism". 
There are various differences between halal and Islam regarding the term tourism, so it is often used interchangeably by researchers both conceptually and empirically the same. In principle, halal tourism answers the challenges of the world's growing Muslim population, which is projected to reach 2.2 billion in 2030 or $26.4 \%$ of the world's total population. One of the countries that is developing the concept of halal tourism is Indonesia. It is not surprising that Indonesia always provides amazing surprises. The Indonesian government is directing the focus on its own tourism resources to be further developed and introduced throughout the world (Kusumawati and Huang 2015). One of the tourist objects that is being developed using the concept of halal tourism is Lake Toba, North Sumatra. Recently, news circulated that Lake Toba would serve as Halal Tourism. Halal tourism focuses on indicators, namely the demand side and activity of tourists who visit Lake Toba. Several research results have explained, what factors influence the concept of halal tourism in tourist objects, namely travel attitude and travel lifestyle [7]-[9]. The results of the study (Jalilvand, Ebrahimi, and Samiei 2013) state that travel attitude is very influential on halal tourism activities in Iran as a Muslim majority country. Furthermore, the results of the research. The research explains that halal tourism is a way of life for people in the world who want facilities and activities that are guaranteed to be halal. Travel attitude also puts forward the attitude of tourists who travel to keep up with the times and the environment as part of lifestyle values that must be fulfilled (Bianchi, Pike, and Lings 2014). The purpose of this study is to see how much influence travel attitude and travel lifestyle have on halal tourism in Lake Toba, Indonesia.

\section{Literature and Hypothesis}

\section{Travel Attitude and Travel Lifestyle}

Attitude is an important reason that is profitable or unfavorable in every activity [11]. Travel attitude describes the attitude that is highlighted when making a trip. Each trip that is made results in an evaluation in expressing the preferences of a tourist in a tourist entity. Travel lifestyle as a lifestyle in fulfilling the desire to keep up with the times. Based on the results have explained the relationship travel attitude on travel lifestyle. The results of the study [10], explain that lifestyle is closely related to one's attitude in making a long journey. Attitudes provide an evaluation of the choice of tourists in determining certain tourist objects as part of their lifestyle. The results of this study are also supported by the opinion, that a person's attitude in carrying out tourism activities depends on the lifestyle of the tourist, that it can influence the value of a person's lifestyle through traveling attitudes. Based on literature, hypotheses can be taken:

H1: Travel attitude has a positive effect on travel lifestyle

\section{Travel Atttitude and Halal Tourism}

Travel attitude is an effective result of a tourist's decision to choose a tourist attraction as a tourist destination [12]. According to the theory of behavioral intention is influenced by attitudes, subjective norms and control that is felt by everyone. In the context of tourism, travel attitude is an influential attitude in determining whether a potential destination is chosen as part of the decisions taken and the final destination selection. Travel attitudes play an important role in attitudes based on knowledge and belief towards the intended object, including tourist objects. Tourists have desires that determine their desires in determining tourist destinations, including halal tourism. Tourism 
services and activities must be in accordance with Islamic law which is often referred to as halal tourism. Tourism is part of the activities of people who travel and stay in places outside their normal environment for not more than one consecutive year for recreation and business. Halal which means it is allowed by religious teachings. 15 The attitude of traveling is closely related to halal activities, which determine the attitude of tourists through knowledge and belief. Halal which has a positive value on self-confidence in traveling. Several research results explain that travel attitude has an effect on halal tourism. The results of the study (Henderson 2015) show that the attitude of tourists depends on their belief in the intended tourist destination including restaurants, hotels and maximum public services including halal tourism. Based on literature, hypotheses can be taken:

H2: Travel attitude has a positive effect on halal tourism

\section{Travel lifestyle and Halal Tourism}

Research has shown that everyone who meets their lifestyle needs to group and plan long trips to specific attractions within a week. The travel lifestyle is used as one of the most effective in psychographic segmentation. In addition, in the 20th century, travel lifestyle studies related to consumer lifestyles, demographics, and the impact of domestic and international travel activities were developed. Tourist lifestyles are also changing rapidly. Lifestyle reflects the polarization between wants and needs. Many tourist objects, such as Halal tourism in different parts of Indonesia, are attractively designed to better meet your needs. The effectiveness of the halal status of tourist objects is considered a special attraction for visiting tourists. Visits with unique conveniences, filled with reliance on available halal products. Halal Tourism is the latest concept of tourism that sells Halal products in various. Recent Muslim tourists believe that halal tourism is a benchmark in determining the right choice and in accordance with religious teachings. Several studies have explained the relationship between travel lifestyle and halal tourism. The results of the research [16], suggest that the lifestyle has a high desire to be fulfilled through the demand for halal labels that exist in several tourist objects. When the halal label is used, the tourists feel that their wishes are fulfilled, giving rise to confidence in carrying out tourism activities. The results of the study, explain that travel lifestyle affects the demand side and halal activity in halal tourism activities in Iran. Based on literature, hypotheses can be taken:

H3: travel lifestyle berpengaruh positif terhadap halal tourism

\section{Research Methods}

The survey was conducted in July 2020 at a tourist attraction on Lake Toba, Indonesia. The respondents to the survey were tourists who visited Lake Toba's motorcycle taxi, and up to 200 respondents used sampling techniques, which are targeted samplings. A total of 210 surveys were returned and 200 valid responses were analyzed. The survey uses a 7-point Likert scale and Smartpls 3.0 analytical data. The sample consists of 200 respondents, 130 females and 70 males. Of the 130 respondents, the largest age group is 17 to 23 years old, followed by 30 to 35 years old. Most of the visitors are 110 respondents who go to high school. 
Table 1. Tourists Characteristics

\begin{tabular}{l|c|c}
\hline \multicolumn{2}{l}{ Frequency } & Percentage\% \\
\hline Gender (\%) & 70 & 35 \\
\hline Male & 130 & 65 \\
\hline Female & \multicolumn{2}{l}{} \\
\hline Level of education (\%) & 110 & 55 \\
\hline High school & 26 & 13 \\
\hline Diploma degree & 74 & 37 \\
\hline Bachelor degree & 10 & 5 \\
\hline Master's degree & & 55 \\
\hline Age (\%) & 110 & 32 \\
\hline $17-23$ & 64 & 8 \\
\hline $24-29$ & 16 & 5
\end{tabular}

Source: Primary data, 2020

\section{Results}

\section{Data Analysis}

Table 2. Value Factor Loading, Avarage Variance Extracted (AVE), Composite Reliability (CR), and Cronbach Alpa (CA) From Each Latent Variables

\begin{tabular}{|c|c|c|c|c|}
\hline Question items & Factor Loading & Construct Reliability & Cronbanch Alpa & AVE \\
\hline \multicolumn{5}{|c|}{ Travel Behavior (TB) } \\
\hline TA1 & 0.810 & \multirow{6}{*}{0.810} & \multirow{6}{*}{0.810} & \multirow{6}{*}{0.655} \\
\hline TA2 & 0.568 & & & \\
\hline TA3 & 0.560 & & & \\
\hline TA4 & 0.701 & & & \\
\hline TA5 & 0.723 & & & \\
\hline TA6 & 0.800 & & & \\
\hline \multicolumn{5}{|c|}{ Travel lifestyle (TL) } \\
\hline TL1 & 0.560 & \multirow{5}{*}{0.876} & \multirow{5}{*}{0.712} & \multirow{5}{*}{0.554} \\
\hline TL2 & 0.562 & & & \\
\hline TL3 & 0.644 & & & \\
\hline TL4 & 0.540 & & & \\
\hline TL5 & 0.682 & & & \\
\hline \multicolumn{5}{|c|}{ Halal Tourism (HT) } \\
\hline HT1 & 0.670 & \multirow{6}{*}{0.868} & \multirow{6}{*}{0.890} & \multirow{6}{*}{0.543} \\
\hline HT2 & 0.556 & & & \\
\hline HT3 & 0.659 & & & \\
\hline HT4 & 0.698 & & & \\
\hline HT5 & 0.517 & & & \\
\hline HT6 & 0.600 & & & \\
\hline
\end{tabular}




\begin{tabular}{|l|l|l|l|l|}
\hline HT7 & 0.613 & & & \\
\hline
\end{tabular}

Source: Primary data, 2020

\section{Validity and Reliability}

Based on Table 2 of the findings, use configuration reliability to measure reliability. In general, the Configuration reliability value is 0.8 . Build reliability for travel settings 0.810 , travel lifestyle 0.876 , and halal tourism 0.868 . There are two measures for factor loading. The first measurement was factor loading, and the minimum convergence validity requirement for this study was set to 0.5 (Ringle et al., 2014). Table 2 shows that all the indicators in this study are valid. The second measurement of the extracted mean variance (AVE) value. Below are the AVE values for the Travel Attitude 0.655, Travel Lifestyle 554, and Halal Tourism 0.543 variables. The AVE total is calculated as needed. Therefore, it ensures that all variables are valid.

\section{Evaluation of Inner Models (Structural Model)}

Table 3. Summary of Research Findings

\begin{tabular}{|c|c|c|c|}
\hline Direct Effect & & Positive Effect & Significant \\
\hline Independent & Dependent & Estimate & P Values \\
\hline Travel Attitude & Travel Lifestyle & 0.512 & 0.001 \\
\hline Travel Attitude & Halal Tourism & 0.505 & 0.008 \\
\hline Travel Lifestyle & Halal Tourism & 0.410 & 0.003 \\
\hline
\end{tabular}

Source: Primary data, 2020

\section{Discussions and Results}

\section{Direct Effect}

Based on Table 3 , the hypothesis is confirmed and implemented. The results show that all hypotheses $\mathrm{H} 1, \mathrm{H} 2$, and $\mathrm{H} 3$ that have a positive effect have been answered. $\mathrm{P}$ value between travel behavior and halal tourism \& 1t; 0.001 (Table 3), significance less than 0.005 . That means that the attitude of travel has a great impact on the lifestyle of travel. The coefficient path value between travel behavior and halal tourism is 0.512 . The coefficient value indicates that travel attitude has a positive impact on the travel lifestyle. Attitude is an important reason for any benefit or disadvantage in any activity [11]. Travel attitudes represent a psychological tendency represented by a positive or negative evaluation by tourists for a particular activity. Tourist attitudes are composed of cognitive and emotional [17]. Travel attitudes represent attitudes that are emphasized during the trip. Every trip carried out leads to a rating that represents the tastes of tourists at the tourist facility [18]. Travel lifestyle as a lifestyle in fulfilling the desire to keep up with the times. The better the attitude of the tourists in evaluating the activities carried out, the better the tourist lifestyle will be fulfilled by the facilities and infrastructure that support tourist activities, including activities carried out by tourists at Lake Toba attractions.

Based on P value between travel behavior and halal tourism \& 1t; 0.008 (Table 3), significance less than 0.005 . This means that the attitude of travel has a great influence on halal tourism. Coefficient pass value between travel lifestyle and halal tourism 0.410 . The coefficient values indicate that the 
travel lifestyle has a positive impact on halal tourism. In the tourism context, travel attitudes are influential in deciding whether to choose potential travel destinations as part of the choices made and final destination choices [19]. Travel attitudes play an important role in attitudes based on knowledge and trust in the target property, including tourist properties. All tourists have the desire to determine his or her desires when deciding on a tourist destination, including Halal tourism. Tourism services and activities must comply with Islamic law, often referred to as halal tourism [4]. Travel attitudes are closely linked to halal activities that determine tourist attitudes through knowledge and beliefs. Halal is a positive value for self-confidence while traveling. The better the attitude of Islamic tourists visiting the tourist destinations of Lake Toba, the better the Islamic teachings, namely the facilities and infrastructure of Halal tourism. More institutions that support the activities of Islamic tourists provide a useful assessment of the decision to take a tour, namely travel attitude. Based on $\mathrm{P}$ value between travel lifestyle and halal tourism \& 1t; 0.003 (Table 3), significance less than 0.005 . This means that the travel lifestyle has a major impact on halal tourism. The lifestyle of tourists is changing rapidly. Lifestyle reflects the polarization between wants and needs. Many tourist facilities, including halal tourism in different parts of Indonesia, are attractively designed to better meet their needs [20]. The validity of halal status on tourism objects is considered as a special attraction for tourists who will visit. A visit that has its own convenience to be fulfilled through trust in available halal products. Halal tourism is the latest tourism concept that sells halal products in various tourist destinations including hotels, restaurants and guaranteed public services. This is the basis for tourists to make tourist visits, including meeting the demands of world Muslim tourists. Recent Muslim tourists believe that halal tourism is a benchmark in determining the right choice and in accordance with religious teachings. A better travel lifestyle for tourists will affect halal tourism, which belongs to certain tourism objects, including Lake Toba. The lifestyle is eager to be met by the demand for halal labels at some tourist facilities. By using the Halal label, tourists feel that their wishes have come true and are confident in conducting tourism activities. The results of this study empirically prove that the travel lifestyle is towards halal tourism. The results of this study support or agree with a previous study by [9] explaining that travel lifestyles influence demand and halal activity in Iran's halal tourism activities. The lifestyle of Islamic tourists on Lake Toba will be better depending on how tourists' needs and desires are met through Halal tourism.

\section{Conclusion}

This study was conducted to determine the impact of different travel attitudes, travel lifestyles and halal tourism on the tourist attractions of Lake Toba, Indonesia. The results of the data analysis show that the proposed hypothesis was totally accepted. First, travel attitudes have a positive and important impact on halal tourism. It is a travel lifestyle as a lifestyle that fulfills the desire to catch up with the times. The better the tourist's attitude in assessing the activities carried out, the more the facilities and infrastructure that support the tourist's activities, including the tourist's activities at the Lake Toba attraction, will enhance the tourist's lifestyle. It will be better filledSecondly, travel attitude has a positive and significant impact on the travel lifestyle. Travel attitude plays an important role in attitudes based on knowledge and trust in the intended object, including tourist objects. Every tourist has a desire that determines his desire in determining tourist destinations, including halal tourism. Third, the travel lifestyle has a positive and significant effect on halal 
tourism. This is because the travel lifestyle of tourists will have an influence on halal tourism which is owned by certain tourist objects, including Lake Toba. Lifestyle has a high desire to be fulfilled through the demand for halal labels on several tourist objects. When the halal label is used, the tourists feel that their wishes are fulfilled, giving rise to confidence in carrying out tourism activities.

\section{References}

[1] N. Collins-kreiner and G. Wall, "Tourism and Religion : Spiritual Journeys and Their Consequences," pp. 689-707, 2015.

[2] S. P. Hotel, K. Lumpur, and T. Duman, "Value of Islamic Tourism Offering: Perspectives from the Turkish Experience Value of Islamic Tourism Offering : Perspectives from the Turkish Experience," no. July, 2011.

[3] J. C. Henderson and J. C. Henderson, "Tourism and Hospitality Research POPULATION AND ISLAMIC," vol. 10, no. 3, pp. 246-254, 2010.

[4] H. El-gohary, "Halal tourism, is it really Halal ?," TMP, 2015.

[5] I. Hamza, "Islamic Tourism : Exploring Perceptions \& Possibilities in Egypt," no. January, 2012.

[6] J. Zhang, J. Wang, S. D. Min, K. K. Chen, and H. Huang, "Influence of curriculum quality and educational service quality on student experiences: A case study in sport management programs," $J$. Hosp. Leis. Sport Tour. Educ., vol. 18, pp. 81-91, 2016.

[7] R. Etminani-ghasrodasht, M. Paydar, and S. Hamidi, "SC," Sustain. Cities Soc., 2018.

[8] A. M. W. Leong, S. S. Yeh, Y. C. Hsiao, and T. C. T. C. Huan, "Nostalgia as travel motivation and its impact on tourists' loyalty," J. Bus. Res., vol. 68, no. 1, pp. 81-86, 2015.

[9] S. Razzaq, C. M. Hall, and G. Prayag, "The capacity of New Zealand to accommodate the halal tourism market - Or not," TMP, vol. 18, pp. 92-97, 2016.

[10] S. Lee and B. S. Ã, "Cultural influences on travel lifestyle : A comparison of Korean Australians and Koreans in Korea," vol. 28, pp. 505-518, 2007.

[11] S. Kim and J. Jun, "The impact of event advertising on attitudes and visit intentions," J. Hosp. Tour. Manag., vol. 29, pp. 1-8, 2016.

[12] M. F. B. López, N. R. Virto, J. A. Manzano, and J. G. M. Miranda, "Residents' attitude as determinant of tourism sustainability: The case of Trujillo," J. Hosp. Tour. Manag., vol. 35, pp. 36-45, 2018.

[13] M. R. Jalilvand, A. Ebrahimi, and N. Samiei, "Electronic Word of Mouth Effects on Tourists' Attitudes Toward Islamic Destinations and Travel Intention: An Empirical Study in Iran," Procedia Soc. Behav. Sci., vol. 81, no. 2006, pp. 484-489, 2013.

[14] P. S. Manhas, L. A. Manrai, and A. K. Manrai, "ARTICLE IN PRESS G Model Role of tourist destination development in building its brand image: A conceptual model," JEFAS- J. Econ. Financ. Adm. Sci., vol. 33, 2016.

[15] H. G. T. Olya and A. Al-ansi, "Risk assessment of halal products and services : Implication for tourism industry," Tour. Manag., vol. 65, pp. 279-291, 2018.

[16] J. R. Van Eck, G. Burghouwt, and M. Dijst, "Lifestyles, spatial configurations and quality of life in daily travel : an explorative simulation study," vol. 13, pp. 123-134, 2005.

[17] N. Thara, A. Zainal, A. Harun, and J. Lily, "Asia Paci fi c Management Review Examining the mediating effect of attitude towards electronic words-of mouth ( eWOM ) on the relation between the trust in eWOM source and intention to follow eWOM among Malaysian travellers," Asia Pacific Manag. Rev., vol. 22, no. 1, pp. 35-44, 2017.

[18] C. Bianchi, S. Pike, and I. Lings, "Investigating attitudes towards three South American destinations in an emerging long haul market using a model of consumer-based brand equity (CBBE)," Tour. Manag., vol. 42, pp. 215-223, 2014.

[19] M. Reza Jalilvand, N. Samiei, B. Dini, and P. Yaghoubi Manzari, "Examining the structural 
relationships of electronic word of mouth, destination image, tourist attitude toward destination and travel intention: An integrated approach," J. Destin. Mark. Manag., vol. 1, no. 1-2, pp. 134-143, 2012.

[20] R. R. Prayogo and A. Kusumawardhani, "Examining Relationships of Destination Image, Service Quality, e-WOM, and Revisit Intention to Sabang Island, Indonesia," Asia-Pacific Manag. Bus. Appl., vol. 5, no. 2, pp. 85-96, 2016. 